\title{
Effects of energy restriction on acute adrenoceptor and metabolic responses to exercise in obese subjects
}

Citation for published version (APA):

Kempen, K. P. G., Saris, W. H. M., Senden, J. M. G., Menheere, P. P. C. A., Blaak, E. E., \& van Baak, M. A. (1994). Effects of energy restriction on acute adrenoceptor and metabolic responses to exercise in obese subjects. American Journal of Physiology (Consolidated), 267(5), E694-E701. https://doi.org/10.1152/AJPENDO.1994.267.5.E694

Document status and date:

Published: 01/01/1994

DOI:

10.1152/AJPENDO.1994.267.5.E694

Document Version:

Publisher's PDF, also known as Version of record

Please check the document version of this publication:

- A submitted manuscript is the version of the article upon submission and before peer-review. There can be important differences between the submitted version and the official published version of record.

People interested in the research are advised to contact the author for the final version of the publication, or visit the DOI to the publisher's website.

- The final author version and the galley proof are versions of the publication after peer review.

- The final published version features the final layout of the paper including the volume, issue and page numbers.

Link to publication

\footnotetext{
General rights rights.

- You may freely distribute the URL identifying the publication in the public portal. please follow below link for the End User Agreement:

www.umlib.nl/taverne-license

Take down policy

If you believe that this document breaches copyright please contact us at:

repository@maastrichtuniversity.nl

providing details and we will investigate your claim.
}

Copyright and moral rights for the publications made accessible in the public portal are retained by the authors and/or other copyright owners and it is a condition of accessing publications that users recognise and abide by the legal requirements associated with these

- Users may download and print one copy of any publication from the public portal for the purpose of private study or research.

- You may not further distribute the material or use it for any profit-making activity or commercial gain

If the publication is distributed under the terms of Article 25fa of the Dutch Copyright Act, indicated by the "Taverne" license above, 


\title{
Effects of energy restriction on acute adrenoceptor and metabolic responses to exercise in obese subjects
}

\author{
K. P. G. KEMPEN, W. H. M. SARIS, J. M. G. SENDEN, \\ P. P. C. A. MENHEERE, E. E. BLAAK, AND M. A. VAN BAAK \\ Department of Human Biology, University of Limburg, and Department of Clinical Chemistry, \\ University Hospital Maastricht, Maastricht, 6200 MD, The Netherlands.
}

\begin{abstract}
Kempen, K. P. G., W. H. M. Saris, J. M. G. Senden, P. P. C. A. Menheere, E. E. Blaak, and M. A. van Baak. Effects of energy restriction on acute adrenoceptor and metabolic responses to exercise in obese subjects. Am. J. Physiol. 267 (Endocrinol. Metab. 30): E694-E701, 1994.-This study was intended to investigate the effects of energy restriction on the acute responses of platelet $\alpha_{2^{-}}$and lymphocyte $\beta_{2^{-}}$ adrenoceptors to exercise in obese female subjects. Seven obese females were restricted to a low-energy formula diet $(2.0$ $\mathrm{MJ} /$ day) for $4 \mathrm{wk}$. As result of the diet, there was a $7.8 \mathrm{~kg}$ weight loss. No significant changes could be detected in sleeping and resting metabolic rate expressed per kilogram fat-free mass. Basal venous glucose, insulin, and norepinephrine levels decreased as a result of the diet, whereas free fatty acid values increased. Before the diet, $60 \mathrm{~min}$ of exercise (45\% peak mechanical power) caused no alteration in the density of lymphocyte $\beta_{2}$-adrenoceptors. At the end of $4 \mathrm{wk}$ of dieting, the density was significantly increased in response to exercise together with a higher thermogenic and lipolytic response and decreased venous insulin levels. Energy restriction resulted in an increased basal platelet $\alpha_{2}$-adrenoceptor density, whereas exercise did not modify density and affinity of platelet $\alpha_{2}$ adrenoceptors. The results indicate that adrenoceptor numbers can be modulated by energy restriction in obesity. Modulation of adrenoceptor density may play a role in increased exercise-induced lipolysis during energy restriction.
\end{abstract}

lymphocyte $\beta_{2}$-adrenoceptors; platelet $\alpha_{2}$-adrenoceptors; catecholamines; thermogenesis; lipolysis

THE ACTIVITY of the sympathetic nervous system (SNS) plays an important role in the regulation of energy expenditure (6). It has been suggested that in obese individuals an impaired activation of the SNS exists that may be responsible for a reduced diet-induced thermogenesis (3). A large part of the SNS-mediated energy expenditure takes place in skeletal muscle, predominantly consisting of $\beta_{2}$-adrenoceptors (18). The adrenoceptor populations of adipose tissue are mainly of the $\beta_{1^{-}}, \beta_{2^{-}}, \beta_{3^{-}}$, and $\alpha_{2}$-type (16), and their role becomes especially important during both exercise and energy restriction, when an increased need for fat as a fuel exists (1). Conditions such as an altered food intake or physical activity are known to affect the activity of the SNS and may thereby influence metabolic rate and substrate metabolism. Acute physical exercise activates the SNS and increases energy expenditure and SNSmediated effects. The increased activation of SNS in response to exercise is accompanied by a rapid elevation of lymphocyte $\beta_{2}$-adrenoceptor density in normalweight healthy subjects $(19,20)$. To our knowledge, changes in $\beta$-adrenoceptor density in response to exer- cise have not been investigated previously in obese subjects.

Weight loss or energy restriction causes a decreased basal sympathetic activity, as measured by lowered basal plasma norepinephrine levels or appearance rates $(5,24)$. The effect of energy restriction on adrenoceptor regulation in obese subjects has not been extensively studied, and the results of previous studies are conflicting. Beside unchanged lymphocyte $\beta_{2}$-adrenoceptor density and affinity $(10)$, increased numbers of $\beta_{2}$-adrenoceptors have been shown on femoral adipocytes (22). Also, platelet $\alpha_{2}$-adrenoceptor density has been reported to increase $(11,28)$ or not to change (5) in response to energy restriction, whereas $\alpha_{2}$-adrenoceptor density of adipocytes has been shown to decrease (22).

The aims of the present study were to investigate whether a single bout of exercise results in a change of blood cell $\alpha_{2}$-and $\beta_{2}$-adrenoceptor numbers in obese subjects and whether energy restriction influences basal and exercise-induced changes in $\alpha_{2^{-}}$and $\beta_{2^{-}}$-adrenoceptor numbers. To investigate whether changes in adrenoceptor numbers are associated with functional consequences for energy metabolism, metabolic parameters were also measured.

\section{SUBJECTS AND METHODS}

\section{Subjects}

Seven female subjects, ages $20-45$ yr (mean age $36 \pm 2 \mathrm{yr}$ ), participated in the study. They were selected on the basis of their body mass index (BMI; $28-38 \mathrm{~kg} / \mathrm{m}^{2}$ ) and had shown a stable weight over the previous 6 mo. All subjects were medically screened to exclude metabolic abnormalities. The subjects were premenopausal and showed a normal regular menstrual cycle. One was taking contraceptives during the study period. They were normotensive and used no medication during the study. Descriptive data of the subjects are shown in Table 1. The subjects were informed about the nature of the investigation and gave their informed consent. The study protocol was reviewed and approved by the university's ethical committee.

\section{Procedure}

The study period lasted 4 wk. Measurements of body composition, sleeping metabolic rate (SMR), resting metabolic rate (RMR), maximal aerobic capacity, exercise-induced thermogenesis, and adrenoceptor numbers were performed before the start of the study and at the end of 4 wk of energy restriction. Measurements were done in approximately the same phase of the menstrual cycle before and at the end of the diet. 
Table 1. Changes in body composition, energy expenditure, and maximal aerobic power in response to 4-wk diet

\begin{tabular}{|c|c|c|c|}
\hline & Weeh 0 & Week 4 & $\begin{array}{c}P \text {-value, } \\
\text { week O vs. } \\
\text { week } 4\end{array}$ \\
\hline Weight, kg & $91.1 \pm 2.6$ & $83.0 \pm 2.5$ & 0.05 \\
\hline Body mass index, $\mathrm{kg} / \mathrm{m}^{2}$ & $32.9 \pm 0.9$ & $30.1 \pm 0.9$ & 0.05 \\
\hline Body fat. $\%$ & $43.9=1.3$ & $41.5 \pm 1.7$ & 0.05 \\
\hline Fat mass, $\mathrm{kg}$ & $40.4 \pm 1.8$ & $34.6 \pm 1.7$ & 0.05 \\
\hline Fat free mass, $\mathrm{kg}$ & $51.1 \pm 1.7$ & $48.8 \pm 2.0$ & 0.05 \\
\hline $\mathrm{SMR}, \mathrm{kJ} \cdot \mathrm{kg} \mathrm{FFM}^{-1} \cdot \mathrm{h}^{-1}$ & $5.54 \pm 0.24$ & $5.22 \pm 0.10$ & NS \\
\hline $\mathrm{RMR}, \mathrm{kJ} \cdot \mathrm{kg} \mathrm{FFM}-1 \cdot \mathrm{h}^{-1}$ & $6.00 \pm 0.24$ & $5.58 \pm 0.22$ & NS \\
\hline $\mathrm{W}_{\max }, \mathrm{W}$ & $192 \pm 7$ & $186 \pm 11$ & NS \\
\hline$\dot{\mathrm{V}}_{2 \max }, \mathrm{ml} \cdot \mathrm{kg} \mathrm{BW}-1 \cdot \min ^{-1}$ & $27.9 \pm 1.2$ & $27.1 \pm 1.4$ & NS \\
\hline
\end{tabular}

Values are means $\pm \mathrm{SE}$ for 7 subjects. Diet is $2.0 \mathrm{MJ} /$ day, $P$ value based on Wilcoxon's signed-rank test. SMR, sleeping metabolic rate; RMR, resting metabolic rate; FFM, fat-free mass; $W_{\text {max }}$, peak mechanical power; $\mathrm{V}_{2 \max }$, maximum $\mathrm{O}_{2}$ uptake; $\mathrm{BW}$, body wt; NS, not significant.

Diet

Subjects were restricted to a low-energy formula diet (Modifast; Sandoz, Switzerland) containing 2.0 MJ/day for $4 \mathrm{wk}$. It provided $50 \mathrm{~g}$ carbohydrates, $52 \mathrm{~g}$ protein, $7 \mathrm{~g}$ fat, $1.1 \mathrm{~g}$ sodium per day, and a micronutrient content that meets the Dutch recommended daily allowance. During the energy-restriction period, the subjects came to the laboratory once a week to have their weight measured.

\section{Measurements}

Body composition. During the study, body weight was measured weekly on a digital balance accurate to $0.1 \mathrm{~kg}$. Before and at the end of the diet period, body fat was determined by hydrostatic weighing. Residual lung volume was measured with a spirometer (Volugraph 2000; Mijnhardt, The Netherlands) at the moment of underwater weighing. The percentage of body fat was calculated from body density using the method proposed by Siri (26),

Energy expenditure. SMR was measured using a computerized open-circuit, indirect caloric chamber $\left(14 \mathrm{~m}^{3}\right)$ equipped with a bed, toilet, television set, and chair. The volume of air drawn through the chamber was measured by a dry-gas meter (Schlumberger, Dordrecht, The Netherlands) and continuously analyzed by a paramagnetic $\mathrm{O}_{2}$-analyzer (Servomex, Crowborough, UK) and an infrared $\mathrm{CO}_{2}$-analyzer (Hartmann and Braun, Frankfurt, Germany). Airflow rate and the $\mathrm{O}_{2}$ and $\mathrm{CO}_{2}$ concentrations of the ingoing and outgoing air were used to compute $\mathrm{O}_{2}$ consumption and $\mathrm{CO}_{2}$ production on-line through an automatic acquisition system interfaced with a Macintosh computer (Apple Computer, Cupertino, CA). The subjects remained in the respiration chamber for $12 \mathrm{~h}$ (19000700). SMR was calculated during the sleeping period between 0300 and 0600 and controlled for physical activity by a Doppler radar system. RMR was measured using an open-circuit ventilated hood system. RMR was determined during $30 \mathrm{~min}$ between 0730 and 0830 while the subjects were resting supine. Subjects had fasted for $\geq 12 \mathrm{~h}$ and had slept in the institute. RMR was calculated according to Weir's formula (31).

Maximum aerobic capacity. Maximum aerobic capacity was determined at least 2 days, and at most 4 days, before the measurement of exercise-induced thermogenesis. Each subject's maximal $\mathrm{O}_{2}$ uptake $\left(\dot{\mathrm{VO}}_{2 \max }\right)$ and peak mechanical power $\left(\mathrm{W}_{\max }\right)$ were measured by using an incremental exercise testi on an electromagnetically braked cycle ergometer (Lode, The Netherlands). $W_{\max }$ was defined as the maximum power a subject could maintain for $1 \mathrm{~min}$. After an initial period of 5 min of cycling at $40 \mathrm{~W}$ and $4 \mathrm{~min}$ at $80 \mathrm{~W}$, the workload was increased by $20 \mathrm{~W} / \mathrm{min}$ until the subjects were exhausted. During the test, ventilatory and gas-exchange responses were measured continuously, using a computerized open system (Sensormedics 2900, Anaheim, CA). Heart rate was recorded continuously by a conventional electrocardiogram system. Criteria for maximal exercise were forced ventilation, leveling off of oxygen uptake, or a respiratory exchange ratio (RER) exceeding 1.1. The highest oxygen uptake $\left(\mathrm{V}_{2}\right)$ achieved for at least $30 \mathrm{~s}$ was taken as $\mathrm{VO}_{2 \max }$.

Exercise-induced thermogenesis. Exercise-induced thermogenesis was measured after an overnight fast. Before the start of the experiment, between 0800 and 0830 , a cannula was inserted in an antecubital vein of a forearm for blood sampling. Measurements were started $30 \mathrm{~min}$ after insertion of the catheter. The exercise protocol consisted of $60 \mathrm{~min}$ of exercise on a bicycle ergometer at a workload of $45 \%$ of the previously estimated $\mathrm{W}_{\max }$. The exercise was preceded by a 30 -min supine rest period (basal measurements) and followed by a $60-\mathrm{min}$ recovery period with the subject in supine rest. Respiratory exchange measurements were done continuously during the basal and recovery periods by means of computerized opencircuit indirect calorimetry, using a ventilated hood system. During exercise, respiratory exchange responses were measured periodically for a total of $30 \mathrm{~min}, 5$ min each time, using a computerized open system (Sensormedics 2900). The electrocardiogram was monitored continuously during the experiment.

Blood samples were collected in the basal state and at timed intervals during the exercise and recovery periods. Hematocrit, glucose, free fatty acids (FFA), and glycerol were determined before exercise $(t=-30$ and $0 \mathrm{~min})$, during exercise $(t=$ $5,15,30$, and $60 \mathrm{~min}$ after starting exercise), and during the recovery period $(t=75,90$, and $120 \mathrm{~min})$. Insulin, glucagon, and catecholamines were analyzed at $t=-30,0,30,60,90$, and 120 min. Extra blood samples were taken at $t=0,60$ (during exercise), and $120 \mathrm{~min}$ for determination of density and affinity of $\alpha_{2}$ and $\beta_{2}$-adrenoceptors.

\section{Analytical Procedure}

Plasma of heparinized blood was used for the determination of glucose by means of a hexokinase method (Cobas Bio; Roche Diagnostics, Hoffmann-La Roche, Basel, Switzerland). Hematocrit was determined by a microcapillary system. Serum was prepared for FFA analyses (Wako, NEFA C; Wako Chemicals, Neuss, Germany) and glycerol (Boehringer, Mannheim, Germany). Plasma insulin was measured, after polyethylene glycol precipitation to eliminate proinsulin and antibodies against insulin, using a double-antibody radioimmunoassay for human insulin (Kabi Pharmacia Diagnostics, Uppsala, Sweden). Glucagon levels were measured using a specific radioimmunoassay (Diagnostic Products, Los Angeles, CA). Concentrations of plasma epinephrine and norepinephrine, sampled with heparine and put into glutathione containing tubes on ice, were determined by means of high-performance liquid chromatography (27). The density of $\alpha_{2}$-adrenoceptors was assessed on platelets using $\left[{ }^{3} \mathrm{H}\right]$ yohimbine binding (21), whereas the density of $\beta$-adrenoceptors was assessed on lymphocytes (8) by means of [125T]iodocyanopindolol (ICYP).

Platelets and lymphocytes. Platelets and lymphocytes were isolated from $20 \mathrm{ml}$ blood anticoagulated with $2 \mathrm{ml} \mathrm{EDTA}(1 \%$ wt/vol). The blood sample was immediately centrifuged at 250 $\mathrm{g}$ for $12 \mathrm{~min}$ at room temperature. The platelet-rich plasma was removed and centrifuged at $1,600 \mathrm{~g}$ for $10 \mathrm{~min}$. The supernatant was discarded, and the platelet pellet was resuspended in a buffer (0.1\% wt/vol EDTA, $150 \mathrm{mM} \mathrm{NaCl}, \mathrm{pH} 7.5)$. 
Protein determinations were made by the Coomassie brilliant blue method (25). The lymphocytes were harvested at room temperature from Lymphoprep gradients (Nyegaard, Oslo, Norway). Intact lymphocytes were resuspended in $10 \mathrm{ml}$ ice-cold twice-distilled water. Cell counts were performed by means of a hematocytometer.

Platelet and lymphocyte suspensions were homogenized for $15 \mathrm{~s}$ in an Ultra-Turrax. The homogenates were then centrifuged at $45,000 \mathrm{~g}$ for $30 \mathrm{~min}$. The resulting pellets were diluted with $10 \mathrm{ml}$ ice-cold twice-distilled water and incubated for 45 $\min$ at $4^{\circ} \mathrm{C}$ to complete lysis. The preparations were then centrifuged at $45,000 \mathrm{~g}$ for $30 \mathrm{~min}$, and the final pellets were resuspended in $4 \mathrm{ml}$ ice-cold incubation buffer $(0.9 \% \mathrm{NaCl}, 10$ $\mathrm{mM}$ tris(hydroxymethyl)aminomethane $\cdot \mathrm{HCl}, \mathrm{pH} 7.5$ ). These suspensions were used for the binding assays.

Receptor-binding studies. Platelets were studied by means of saturation binding assays using $\left[{ }^{3} \mathrm{H}\right]$ yohimbine. Nonspecific binding was defined as the amount of $\left[{ }^{3} \mathrm{H}\right]$ yohimbine bound in the presence of $10 \mu \mathrm{M}$ phentolamine. Platelets were incubated with eight concentrations $(0.5-10.5 \mathrm{nM})$ of $\left[{ }^{3} \mathrm{H}\right]$ yohimbine (final volume $0.2 \mathrm{ml}$ ) for $30 \mathrm{~min}$ at $25^{\circ} \mathrm{C}$. Incubation was stopped by the addition of $10 \mathrm{ml}$ of platelets assay buffer, and subsequent rapid filtration through Whatman GF/C filters (Whatman International, Maidstone, UK) placed on a Millipore manifold sampling unit. Filters were additionally rinsed with $10 \mathrm{ml}$ of assay buffer. Radioactivity on the filters was counted in a beta-scintillation counter.

Lymphocyte $\beta$-adrenergic receptors were studied with ICYP, determining nonspecific binding with $1 \mu \mathrm{M}$ propranolol. Lymphocytes were incubated for $60 \mathrm{~min}$ at $37^{\circ} \mathrm{C}$, in assay buffer (final volume $0.2 \mathrm{ml}$ ) in duplicate, using eight concentrations of ICYP $(3-1.80 \mathrm{pM})$ in the absence or presence of $1 \mu \mathrm{M}$ propranolol. The reaction was terminated by the addition of 10 $\mathrm{ml}$ of incubation buffer, and lymphocyte contents were filtered over glass-fiber filters (Gelman type A/E). The tubes and filters were washed with an additional $10 \mathrm{ml}$ of buffer, and the filters were counted in a gamma counter at $80 \%$ efficiency. Number of binding sites $\left(\mathbf{B}_{\max }\right)$ and equilibrium dissociation constant $\left(K_{d}\right)$ were defined according to Scatchard (23). Saturation was obtained in all experiments. Coefficients of variation (CV) for between-subjects variability for density and affinity of $\beta_{2}$-adrenoceptors were $27 \pm 3$ and $36 \pm 4 \%$, respectively; for $\alpha_{2}$-receptors these values were $27 \pm 3$ and $16 \pm 2 \%$. Repeated within-subjects CVs for density and affinity of $\beta_{2}$-adrenoceptors were $19 \pm 2$ and $30 \pm 3 \%$, respectively; for $\alpha_{2}$-receptors these values were $14 \pm 3$ and $9 \pm 1 \%$.

\section{Data Analysis}

Data in the text, Tables 1-3, and Figs. 1-2 are given as means $\pm \mathrm{SE}$. The physiological responses to exercise were analyzed by a repeated-measurements analysis of variance (ANOVA). Total plasma response curves were calculated as the total integrated changes over baseline values [areas under curve (AUC) from $t=0$ to $\left.t=60 \mathrm{~min}\left(\mathrm{AUC}_{0-60}\right)\right]$. The $\mathrm{CV}$ is defined as SD divided by mean, expressed as a percentage. The Wilcoxon's signed-rank test was used to analyze differences between before and at the end of a 4-wk diet. Significance levels were set at $P<0.05$.

\section{Chemicals}

ICYP $(2,000 \mathrm{Ci} / \mathrm{mmol})$ and $\left[{ }^{3} \mathrm{H}\right]$ yohimbine $(89 \mathrm{Ci} / \mathrm{mmol})$ were purchased from Amersham International, UK. All other reagents were obtained from Sigma Chemical, St. Louis, MO.

\section{RESULTS}

\section{Body Composition, Energy Expenditure and Maximal Aerobic Capacity}

The dietary restriction for $4 \mathrm{wk}$ resulted in significant decreases of body weight, fat, and fat-free mass (FFM), as shown in Table 1. SMR and RMR measurements, expressed on the basis of FFM tended to decline, although not significantly $(P=0.09)$. $\dot{\mathrm{V}}_{2 \max }$ and $\mathrm{W}_{\max }$ were not affected by the energy restriction.

\section{$\alpha$ - and $\beta$-Adrenergic Receptors}

Four weeks of energy restriction did not result in a significant change of basal lymphocyte $\beta_{2}$-adrenoceptor density. Before diet, 60-min exercise caused no alteration in the density of lymphocyte $\beta_{2}$-adrenoceptors (Table 2). At the end of the 4th wk of dieting, $B_{\max }$ of lymphocyte $\beta_{2}$-receptors increased significantly in response to exercise. Both exercise and caloric restriction did not significantly change the $K_{d}$ of lymphocyte $\beta_{2-}$ adrenoceptors.

$B_{\max }$ at rest for platelet $\alpha_{2}$-adrenoceptors was signifcantly higher during energy restriction than before diet (Table 2). Exercise did not significantly change $B_{\max }$ or $K_{\mathrm{d}}$ of platelet $\alpha_{2}$-receptors, although during exercise values of $B_{\text {max }}$ tended to be somewhat increased (ANOVA, $P=0.07)$. Caloric restriction did not influence the affinity of platelet $\alpha_{2}$-adrenoceptors.

\section{Exercise-Induced Thermogenesis and Metabolism}

Respiratory gas exchanges and heart rate. Table 3 demonstrates the exercise-induced changes in energy expenditure, respiratory quotient, and heart rate. Exercise resulted in significant increases in energy expenditure, RER, and heart rate (ANOVA, $P<0.05$ ). Energy expenditure at rest, expressed per kilogram FFM, was significantly decreased in response to dieting. The thermogenic response to exercise, expressed per kilogram FFM measured in week 0 , was not significantly different

Table 2. Responses of platelet $\alpha$-receptors and lymphocyte $\beta$-receptors to 60-min exercise before and at end of 4-wk weight reduction

\begin{tabular}{|c|c|c|c|c|}
\hline & \multicolumn{2}{|c|}{$\alpha$-Adrenoceptors } & \multicolumn{2}{|c|}{ B-Adrenoceptors } \\
\hline & $\begin{array}{c}\mathrm{B}_{\mathrm{max}}, \\
\mathrm{fmol} / \mathrm{mg} \text { protein }\end{array}$ & $\begin{array}{l}K_{\mathrm{d}} \\
\mathrm{nM}\end{array}$ & $\begin{array}{c}\mathrm{B}_{\max }, \\
\mathrm{fmol} / 10^{6} \text { cells }\end{array}$ & $\begin{array}{l}K_{\mathrm{d}}, \\
\mathrm{pM}\end{array}$ \\
\hline \multicolumn{5}{|l|}{ Before diet } \\
\hline At rest & $110.8 \pm 18.8$ & $4.3 \pm 0.4$ & $1.44 \pm 0.14$ & $24.9 \pm 1.9$ \\
\hline $\begin{array}{l}\text { During exercise } \\
\text { After } 60-\mathrm{min}\end{array}$ & $143.0 \pm 17.0$ & $4.7 \pm 0.5$ & $1.42 \pm 0.23$ & $27.9 \pm 2.9$ \\
\hline $\begin{array}{c}\text { recovery } \\
\text { At end of diet }\end{array}$ & $128.1 \pm 17.3$ & $4.2 \pm 0.2$ & $1.73 \pm 0.17$ & $34.1 \pm 4.2$ \\
\hline At rest & $167.1 \pm 23.7^{*}$ & $4.7 \pm 0.2$ & $1.67 \pm 0.21$ & $29.0 \pm 2.6$ \\
\hline $\begin{array}{l}\text { During exercise } \\
\text { After } 60-\mathrm{min}\end{array}$ & $210.5 \pm 26.1$ & $5.0 \pm 0.3$ & $2.15 \pm 0.15 \dagger$ & $30.3 \pm 3.0$ \\
\hline recovery & $170.4 \pm 28.8$ & $5.0 \pm 0.3$ & $1.52 \pm 0.17$ & $32.6 \pm 3.0$ \\
\hline
\end{tabular}

Values are means \pm SE. Exercise is at $45 \% \mathrm{~W}_{\max }$. $\mathrm{B}_{\max }$, maximal binding sites; $K_{\mathrm{d}}$, dissociation constant. * Significantly different from week $0 ; P<0.05$ Wilcoxon's signed rank test. $†$ Significantly different from resting and recovery value; $P<0.05$ analysis of variance for repeated measurement, post hoc Wilcoxon's signed-rank test. 
Table 3. Respiratory and heart rate responses during 60-min exercise before and at end of 4-wk weight reduction

\begin{tabular}{|c|c|c|c|c|c|c|c|}
\hline & \multirow{2}{*}{ Week } & \multirow{2}{*}{ Rest } & \multicolumn{4}{|c|}{ Exercise, $\min$} & \multirow{2}{*}{ Recovery } \\
\hline & & & 5 & 15 & 30 & 60 & \\
\hline Energy expenditure, & week 0 & $6.3 \pm 0.3$ & $30.6 \pm 1.5$ & $34.8 \pm 2.2$ & $35.4 \pm 2.2$ & $33.3 \pm 1.9$ & $6.2 \pm 0.3$ \\
\hline $\mathrm{kJ} \cdot \mathrm{kg} F F M^{-1} \cdot \mathrm{h}^{-1}$ & week 4 & $5.5 \pm 0.2^{*}$ & $30.0 \pm 1.2$ & $35.1 \pm 1.7$ & $35.4 \pm 1.6$ & $34.8 \pm 2.3$ & $5.8 \pm 0.2^{*}$ \\
\hline \multirow{2}{*}{$\begin{array}{l}\text { Energy expenditure, } \\
\% \text { from baseline }\end{array}$} & week 0 & 100 & $488 \pm 25$ & $553 \pm 31$ & $562 \pm 30$ & $530 \pm 29$ & $99 \pm 3$ \\
\hline & week 4 & 100 & $553 \pm 23^{*}$ & $646 \pm 29^{*}$ & $652 \pm 28^{*}$ & $637 \pm 32^{*}$ & $106 \pm 2$ \\
\hline \multirow[t]{2}{*}{ Respiratory exchange ratio } & week 0 & $0.85 \pm 0.02$ & $0.95 \pm 0.04$ & $0.91 \pm 0.01$ & $0.89 \pm 0.02$ & $0.92 \pm 0.03$ & $0.84 \pm 0.01$ \\
\hline & week 4 & $0.82 \pm 0.01^{*}$ & $0.90 \pm 0.03^{*}$ & $0.85 \pm 0.02^{*}$ & $0.84 \pm 0.01^{*}$ & $0.88 \pm 0.02$ & $0.75 \pm 0.02^{*}$ \\
\hline \multirow[t]{2}{*}{ Heart rate, beats/min } & week 0 & $72 \pm 3$ & $128 \pm 7$ & $138 \pm 10$ & $142 \pm 10$ & $145 \pm 9$ & $77 \pm 4$ \\
\hline & week 4 & $64 \pm 3^{*}$ & $138 \pm 5$ & $149 \pm 5$ & $151 \pm 6$ & $153 \pm 6$ & $70 \pm 3$ \\
\hline \multirow[t]{2}{*}{ Heart rate, \% from baseline } & week 0 & 100 & $177 \pm 5$ & $190 \pm 9$ & $196 \pm 9$ & $201 \pm 9$ & $107 \pm 8$ \\
\hline & week 4 & 100 & $217 \pm 11^{*}$ & $234 \pm 11^{*}$ & $238 \pm 10^{*}$ & $240 \pm 9^{*}$ & $110 \pm 5$ \\
\hline
\end{tabular}

Values are means $\pm \mathrm{SE}$. Exercise is at $45 \% \mathrm{~W}_{\max }$. ${ }^{*}$ Significantly different from week $0 ; P<0.05$ Wilcoxon's signed-rank test.

from the values of week $4\left(\mathrm{AUC}_{0-60} 1,597 \pm 104\right.$ vs. $1,667 \pm 88 \mathrm{~kJ}, P=0.31$ ). However, energy expenditure expressed as percentage of baseline values was significantly increased after energy restriction (Table 3), which might suggest an increased thermogenic response.

Energy restriction resulted in a significant reduction of RER in rest, and during exercise and recovery periods, compared with the week 0 values. At the end of the diet, RER declined significantly below resting values during recovery, whereas it did not in week 0 . The total integrated responses to exercise of RER of weeks 0 and 4 were not significantly different from each other $\left(\mathrm{AUC}_{0-60}\right.$ $3.11 \pm 1.1$ vs. $2.59 \pm 0.6 / 60 \mathrm{~min} ; P=0.73$ ). Resting heart rate was significantly diminished during energy restriction $(P<0.05)$; however, this was accompanied with a tendency to an increased total integrated response to exercise $\left(\mathrm{AUC}_{0-60} 3,901 \pm 417\right.$ vs. $4,886 \pm 250$ beats $/ 60$ min, week $O$ vs. week $4 ; P=0.063$ ). This increased response in heart rate reached significance if the values are expressed as percentage of basal values (Table 3 ).

Plasma glucose, FFA, glycerol, and hematocrit. Although plasma glucose significantly decreased with dieting from $5.50 \pm 0.12$ to $4.86 \pm 0.17 \mathrm{mmol} / \mathrm{l}(P<0.05)$, exercise did not change plasma glucose level in either week 0 or week 4 (Fig. 1). The total integrated response of glucose tended to be higher after the diet $\left(\mathrm{AUC}_{0-60}\right.$ $-0.5 \pm 12$ vs. $15.3 \pm 6 \mathrm{mmol} / \mathrm{l}$, week 0 vs. week $4 ; P=$ 0.091 ). With dieting, resting plasma FFA values rose from $583 \pm 131$ to $1,134 \pm 186 \mu \mathrm{mol} / 1(P<0.05)$, whereas no change occured in resting plasma glycerol concentrations (Fig. 1). During exercise and recovery, both FFA and glycerol values were significantly higher during the diet in comparison with values before diet. The total integrated response to exercise of glycerol was significantly higher during the diet compared with the values before $\left(\mathrm{AUC}_{0-60} 8,025 \pm 2,170\right.$ vs. $24,737 \pm 3,772$ $\mu \mathrm{mol} / \mathrm{l}$, week 0 vs. week $4 ; P<0.05$ ). Only during the diet did exercise cause significant increments in plasma FFA and glycerol concentrations. With respect to FFA values, the total integrated response was only significantly increased at the end of the diet during recovery $\left(\mathrm{AUC}_{0-60} 28,100 \pm 7,292\right.$ vs. $60,304 \pm 9,983 \mu \mathrm{mol} / \mathrm{l}$, week $O$ vs. week $4 ; P<0.05$ ). This increase was especially apparent 15 and $30 \mathrm{~min}$ after exercise $(t=75$ and $90 \mathrm{~min}$ ). Neither energy restriction nor exercise caused changes in hematocrit.
Plasma insulin, glucagon, and catecholamines. Fasting was associated with a significant decline in resting plasma insulin values from $16.5 \pm 5.2$ to $7.5 \pm 0.8 \mathrm{mU} / 1$ (Fig. 2). After $30 \mathrm{~min}$ of exercise, plasma insulin was still significantly lower during the diet compared with before diet values $(P<0.05)$. Exercise tended to reduce plasma insulin before the diet $(P=0.067)$, whereas no change occurred during exercise at the end of the diet. Total integrated response of plasma insulin during recovery was significantly higher for week 4 compared with values of week $O\left(-474 \pm 268\right.$ vs. $355 \pm 149 \mathrm{mU} \cdot \mathrm{l}^{-1} \cdot 120$ $\min ^{-1}$, week 0 vs. week $4 ; P<0.05$ ). Energy restriction did not change the exercise-induced increments $(P<$ 0.05 ) in plasma glucagon. Also, increases in plasma norepinephrine and epinephrine in response to exercise were not altered by dieting, although resting and recovery values of norepinephrine were significantly decreased during the diet.

\section{DISCUSSION}

The objective of the present study was to investigate the effects of a single bout of exercise and energy restriction on lymphocyte $\beta_{2}$ - and platelet $\alpha_{2}$-adrenocep. tor status in obese subjects. It is known that the metabolic response to exercise is primarily related to the type, duration, and intensity of the exercise performed as well as the physical condition of the subject. In this study, the relative workload of exercise before and at the end of the diet was equal, because this type of dietary restriction did not affect $\mathrm{W}_{\max }$ or $\dot{\mathrm{V}}_{2 \max }$, as confirmed by others (29). Therefore, the responses to exercise before and at the end of the diet can be adequately compared.

Skeletal muscle plays an important role in resting energy expenditure and thermogenesis (4). It has been shown that skeletal muscle mainly contains $\beta_{2}$-adrenoceptors (18), and their role in human energy metabolism has been demonstrated (6). The mobilization of lipids from adipose tissue plays a key role in the regulation of the energy balance at rest and during exercise and becomes even more important during periods of energy deficiency. Human adipose tissue has been shown to contain $\alpha_{2^{-}}, \beta_{1^{-}}$, and $\beta_{2^{2}}$-adrenoceptors that seem to be involved in lipolysis (16). In addition, involvement of $\beta_{3}$-adrenoceptors in lipolysis is suggested (1.5), although the significance of $\beta_{3}$-adrenoceptors in human energy 

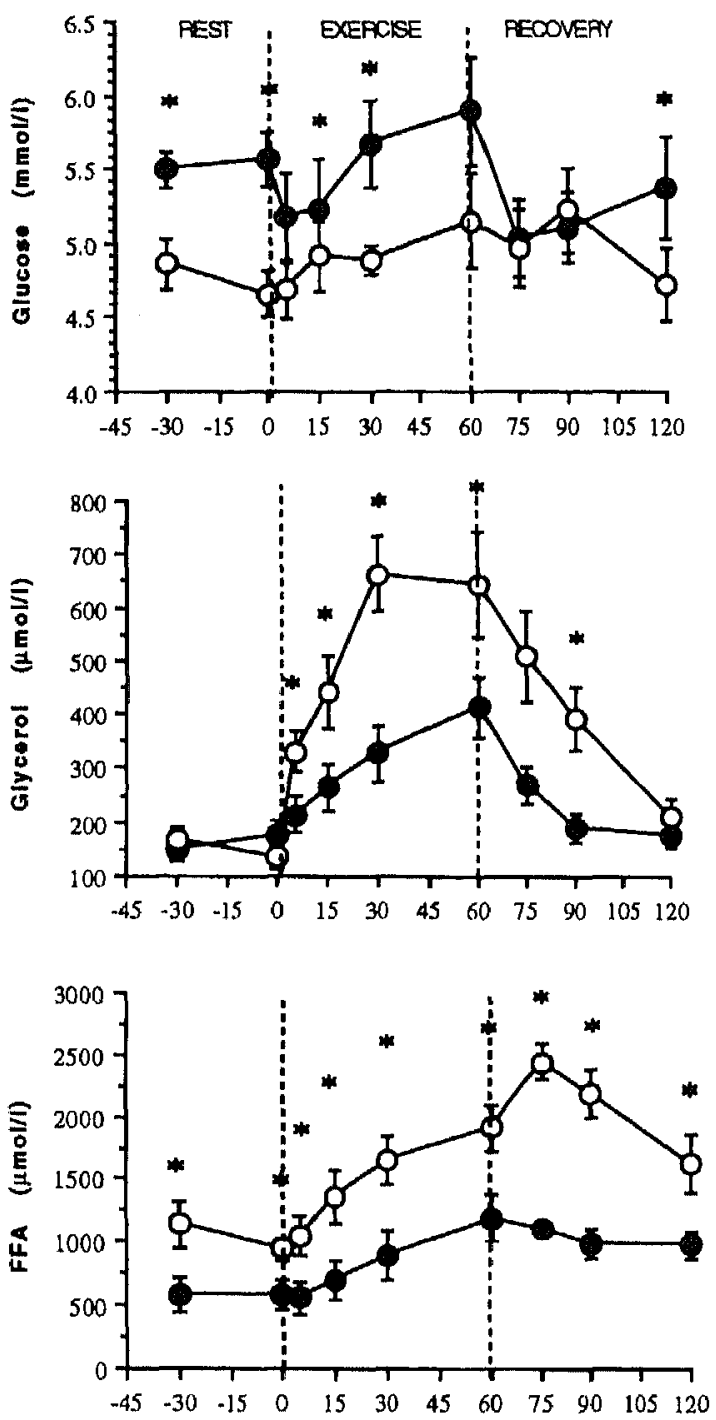

tory effects modulate lipolysis during exercise (2). Moreover, regional differences in lipid mobilization between abdominal and gluteal adipose tissues have been shown during exercise (2) and in vitro catecholamine stimula-
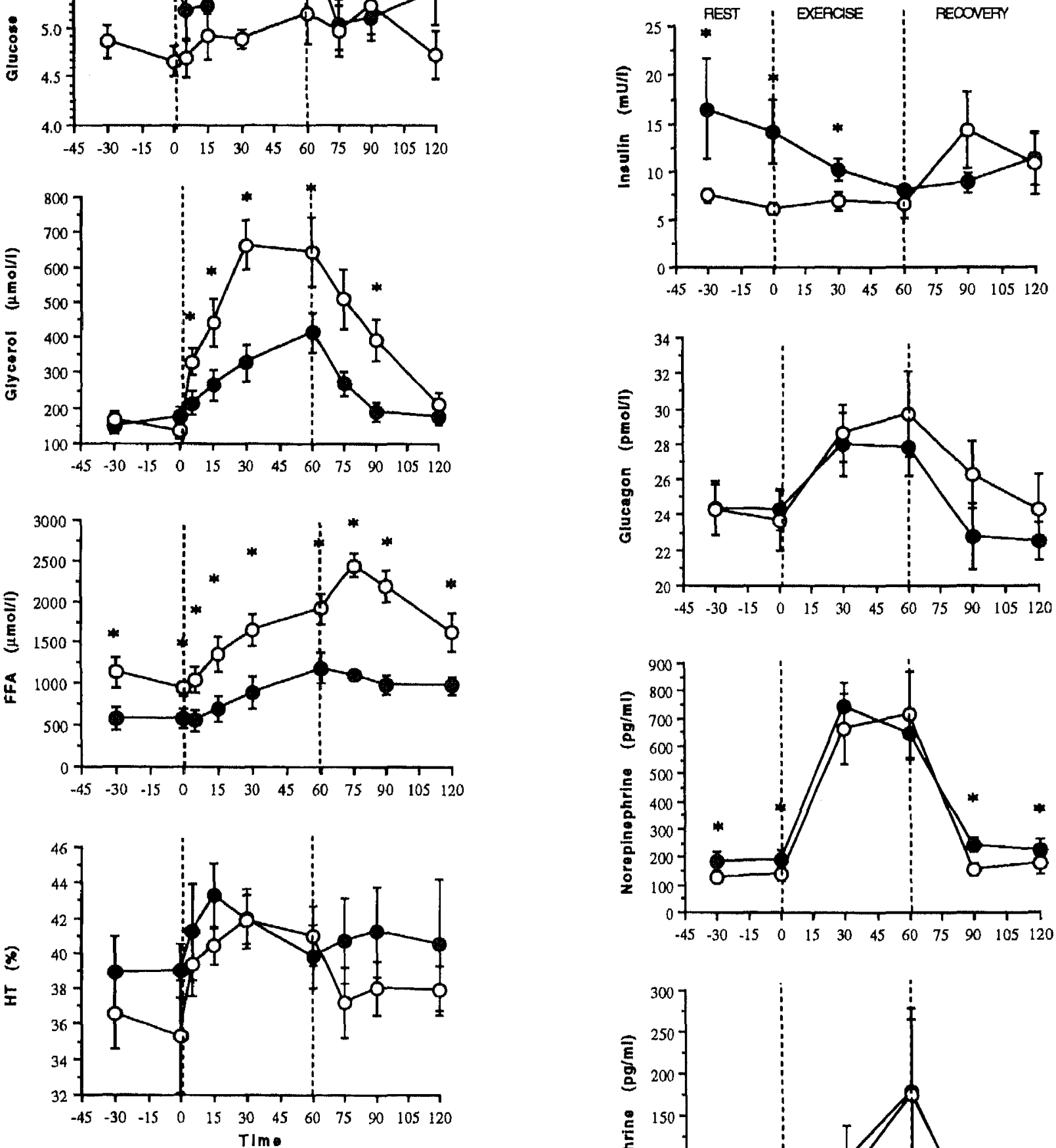

Fig. 1. Venous concentrations of glucose, free fatty acids (FFA) glycerol, and hematocrit (HT) during rest, exercise, and recovery periods in obese females before $(\bullet)$ and at end of 4 -wk diet $(0)$. Values are means $\pm \mathrm{SE} ; n=7$. Repeated measurement analysis of variance (ANOVA), post hoc Wilcoxon's signed-rank test; ${ }^{*} P<0.05$.

metabolism is still debated. With the use of a recently developed microdialysis technique, it was demonstrated that in vivo lipolysis is modulated by $\alpha$-adrenergic inhibitory effects at rest, whereas $\beta$-adrenergic stimula-

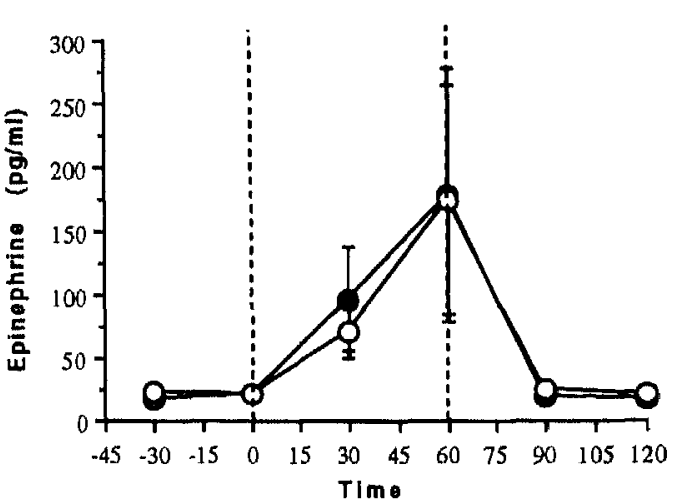

Fig. 2. Venous concentrations of insulin, glucagon, norepinephrine, and epinephrine during rest, exercise, and recovery periods in obese females before $(\bullet)$ and at end of 4 -wk diet $(O)$. Values are means $\pm S E ;$ $n=7$. Repeated measurement ANOVA, post hoc Wilcoxon's signedrank test; ${ }^{*} P<0.05$ 
tion (20) that might be related to differences in the balance of $\alpha_{2}$-and $\beta$-adrenoceptors in these tissues.

For studying $\beta_{2}$-adrenergic receptor function in humans, circulating lymphocytes containing a homogeneous population of $\beta_{2}$-adrenoceptors, excitatory-coupled to adenylate cyclase, are commonly used (8). It has been shown that changes in lymphocyte $\beta_{2}$-adrenoceptor density reflect changes of $\beta_{2}$-adrenoceptor density and responsiveness in solid, less accessible tissues such as heart, myometrium, lung, and skeletal muscle (18). We also found a significant relationship between density of skeletal muscle $\beta_{2}$-adrenoceptors and those of lymphocytes $(r=0.85, P<0.05)$ in this group of obese subjects. Liggett et al. (18) showed that this reflection is only valid in a subtype-specific fashion. Therefore, for tissues containing mixed $\beta$-adrenoceptor subtypes, such as human heart or adipose tissue, the use of lymphocyte $\beta_{2}$-adrenoceptors as a tool for predicting $\beta$-adrenoceptor status may be limited.

Human platelets containing a homogeneous population of $\alpha_{2}$-adrenoceptors inhibitory-coupled to adenylate cyclase are a model commonly used to study changes of $\alpha_{2}$-adrenoceptors in humans (21). Changes in platelet $\alpha_{2}$-adrenoceptor density have been demonstrated to correlate with changes of $\alpha_{2}$-adrenoceptor density in myometrial membranes (9). However, despite similar in vitro properties of $\alpha_{2}$-adrenoceptors in platelets and various tissues, it is still not clear whether $\alpha_{2}$ adrenoceptor changes measured on platelets are related to changes occurring in other human tissues (11).

It has been shown that both acute and prolonged physical exercise causes an elevation of lymphocyte $\beta_{2}$-adrenoceptor density $(7,19,20)$, accompanied by increased responsiveness as measured by isoprenalineinduced adenosine $3^{\prime}, 5^{\prime}$-cyclic monophosphate production, in normal healthy subjects. In our study with obese female subjects, this exercise-induced elevation occurred only at the end of 4 wk of dieting. If the observed upregulation of lymphocyte $\beta_{2}$-adrenoceptor numbers in response to exercise at the end of the the diet reflects changes in adrenoceptor status in metabolic tissues, then upregulation might be associated with functional consequences for aspects of thermogenesis and substrate metabolism that are $\beta_{2}$-receptor mediated. One of the consequences is likely to be the observed overall increase in lipolysis, as indicated by increased plasma FFA and glycerol values and responses, resulting in increased fat oxidation, as indicated by the lowered RER values. Furthermore, the tendency to increased exerciseinduced thermogenic and heart rate responses at the end of energy restriction might also be associated with the observed upregulation of lymphocyte $\beta_{2}$-adrenoceptor numbers. The increased basal lipolysis and fat oxidation, despite a lack of change in basal $\beta_{2}$-adrenoceptor density does not preclude a basal upregulation in response to lower basal SNS activity due to energy restriction, because upregulation may occur distal to the receptor itself at postreceptor level (20).

The decreased resting plasma norepinephrine concentration during energy restriction observed in this study is in agreement with other studies $(5,10,24)$. It has been shown that this is a result of both reductions in appearance and clearance rates of norepinephrine. This might indicate that energy restriction is accompanied by decreased basal SNS activity. The energy restriction did not influence the responses of plasma norepinephrine and epinephrine to exercise. However, exercise resulted in an upregulation of lymphocyte $\beta_{2}$-adrenoceptor numbers at the end of the diet. Together with the observed increased thermogenic, heart rate, and lipolytic responses, it might indicate that energy restriction is accompanied with increased sensitivity to adrenergic stimulation. This seems to agree with several in vivo studies in humans showing an increased lipolytic response to catecholamine infusion during caloric restriction $(1,14)$. In vitro studies on adipocytes showed either no effects or inhibiting effects of catecholamines on lipolysis during dieting $(11,22)$. An explanation for this inconsistency is likely to be found in the absence of hormonal effects in the in vitro system $(13,16)$.

The mechanism of upregulation of lymphocyte $\beta_{2}$ adrenoceptors to acute exposure is still incompletely understood. Externalization of intracellularly sequestered receptor molecules seems to be a tempting possibility, although results are contradictory (20). Furthermore, rapid synthesis of new receptor protein has not been excluded (20). Failure to induce a $\beta_{2}$-adrenoceptor upregulation during exercise in obese subjects may reflect a decreased number of internalized receptors, possibly due to inhibition of receptor protein synthesis or a defect in the mobilization of internal receptors. On the other hand, it has been speculated that the exerciseinduced increase in $\beta_{2}$-adrenergic receptors of mixed lymphocytes can at least partly be explained by a redistribution caused by exercise of circulating cell subsets that differ in their $\beta_{2}$-adrenoceptor numbers (19). Although such changes may contribute to exerciseinduced increase in receptor density, it is unlikely that they would fully explain this increase, since $\beta$-blockade prevents the increase in receptor density but does not block the lymphocytosis (7).

It has also been shown that the upregulation takes place even in situations where there are no changes in the total blood lymphocyte count or the distribution of lymphocyte subpopulations (20). When the number of $\beta$-adrenoceptors in different T-lymphocyte subpopulations was measured during acute exercise, an equal upregulation of $\beta$-adrenoceptors was detected in cells originally containing small numbers of receptors and cells containing large numbers of receptors (20). Even if there are some effects of lymphocytosis on $\beta$-adrenoceptor density, there are no indications that the effects differ before and at the end of the diet.

In the present study, energy restriction resulted in a significant increase in platelet $\alpha_{2}$-adrenoceptor density, as reported in two other studies $(11,28)$ after 4 and 8 wk of moderate diet, respectively. However, Berlin et al. (5) did not find a significant rise in platelet $\alpha_{2}$-adrenoceptor density, probably because of the relative short duration (15 days) of the diet period. However, decreased $\alpha_{2}$ adrenoceptor density on adipocytes (22) has been shown during energy restriction. The observed increase in 
platelet $\alpha_{2}$-adrenoceptor density with energy restriction may represent an upregulation in response to decreased circulating norepinephrine values. Physiological significance of the increased platelet $\alpha_{2}$-adrenoceptor density remains speculative because adequate validation studies are lacking.

Exercise did not modify the platelet $\alpha_{2}$-adrenergic receptor characteristics, either before or after the diet in this study, as confirmed by another study (5). The latter study reported, in contrast, that in lean women exercise resulted in an increase in platelet $\alpha_{2}$-density accompanied with a decrease in affinity, and it was suggested that obese women were unable to desensitize platelet $\alpha_{2}$-adrenoceptors in response to acute physical exercise.

However, the observed effects of energy restriction on SNS activity and adrenoceptor status might have been biased by the accompanying decreased sodium intake. Cignarelli et al. (10) showed that sodium restriction prevailed over the effects of caloric restriction on sympathetic activity, thereby increasing the activity. However, in the study of Cignarelli et al. (10), the sodium intake was extremely low ( $9 \mathrm{mmol} /$ day), and it is unlikely that such strong effects occurred in our study, with a daily sodium intake of $60 \mathrm{mmol}$. Moreover, we did not observe a downregulation of basal adrenoceptor numbers, as has been reported to occur as a result of strict sodium restriction (10). Furthermore, if there are some effects of the decreased dietary sodium intake, only an underestimation of the effects of energy restriction will be measured.

The data collected in this study do not allow us to distinguish between effects of the hypocaloric state and the effects of weight loss. However, they are likely to be the consequence of the combination of the two, because it has been reported that reduced-obese subjects at stable body weight still showed a decreased basal catecholamine release but an increased lipolytic response to hypoglycemia and infused catecholamines, compared with obese and never-obese control subjects (17).

In conclusion, energy restriction in obese females resulted in an exercise-induced upregulation of lymphocyte $\beta_{2}$-adrenoceptors that did not occur before the diet. Therefore, exercise may play a role of importance in the regulation of thermogenesis, especially in the obese. The energy restriction resulted in an increase in basal platelet $\alpha_{2}$-adrenoceptor numbers. This indicates that adrenoceptor numbers can be modulated by energy restriction in obesity. Modulation of adrenoceptor density might play a role in increased exercise-induced lipolysis during energy restriction.

This work was supported by the Netherlands Organization for Scientific Research Grant 900-562-090.

Address for reprint requests: K. P. G. Kempen, Dept. of Human Biology, University of Limburg, PO Box 616, 6200 MD Maastricht, The Netherlands.

Received 4 November 1993; accepted in final form 24 May 1994.

\section{REFERENCES}

1. Arner, P. Adrenergic receptor function in fat cells. Am. J. Clin. Nutr, 55: 228S-236S, 1992 .
2. Arner, P., E. Kriegholm, P. Engfeldt, and J. Bolinder. Adrenergic regulation of lipolysis in sito at rest and during exercise. J. Clin. Invest. 85: 893-898, 1990.

3. Astrup, A., T. Andersen, N. J. Christensen, J. Bülow, J. Madsen, L. Breum, and F. Quaade. Impaired glucoseinduced thermogenesis and arterial norepinephrine response persist after weight reduction in obese humans. Am. J. Clin, Nutr. 51: 331-337, 1990.

4. Astrup, A., J. Bülow, J. Madsen, and N. J. Christensen. Contribution of BAT and skeletal muscle to thermogenesis in duced by ephedrine in man. Am. J. Physiol. 248 (Endocrinol. Metab. 11): E507-E515, 1985.

5. Berlin, I., M. Berlan, B. Crespo-Laumonnier, C. Landault, C. Payan, A. J. Puech, and G. Turpin. Alterations in $\beta$-adrenergic sensitivity and platelet $\alpha_{2}$-adrenoceptors in obese women: effect of exercise and caloric restriction. Clin. Sci. Lond. 78; 81-87, 1990.

6. Blaak, E. E., M. A. van Baak, K. P. G. Kempen, and W. H. M. Saris. Role of $\alpha$ - and $\beta$-adrenoceptors in sympathetically mediated thermogenesis. Am. J. Physiol. 264 (Endocrinol. Metab. 27): E11-E17, 1993.

7. Brodde, O.-E., A. E. Daul, X. L. Wang, M. C. Michel, and O. Galal. Dynamic exercise-induced increase in lymphocyte beta2-adrenoceptors: abnormality in essential hypertension and its correction by antihypertensives. Clin. Pharmacol. Ther. 41: 371$379,1987$.

8. Brodde, O.-E., G. Engel, D. Hoyer, K. D. Bock, and F. Weber. The $\beta$-adrenergic receptor in human lymphocytes: subclassification by the use of a new radio-ligand, $( \pm)_{-125}{ }^{2}$ iodocyanopindolol. Life Sci. 29: 2189-2198, 1981.

9. Brodde, O.-E., U. Seher, M. Nohlen, W. M. Fischer, and M. C. Michel. Correlation between human myometrial and platelet $\alpha_{2}$-adrenoceptor density. Eur. J. Pharmacol. 150; 403$404,1988$.

10. Cignarelli, M., G. de Pergola, G. Garruti, M. Corso, M. R. Cospite, A. Paternostro, V. Romanazzi, and R. Giorgino. Changes in overall plasma norepinephrine turnover and lymphomonocyte beta-adrenoceptor number during combined caloric and sodium restriction in normotensive obese subjects. Int. J. Obes. 14: 429-437, 1990.

11. Crampes, F., M. Marceron, M. Beauville, D. Riviere, M. Garrigues, M. Berlan, and M. Lafontan. Platelet alpha $2^{n}$ adrenoceptors and adrenergic adipose tissue responsiveness after moderate hypocaloric diet in obese subjects. Int. J. Obes. 13: 99-110, 1989.

13. Engfeldt, P., J. Hellmér, H. Wahrenberg, and P. Arner. Effects of insulin on adrenoceptor binding and the rate of catecholamine-induced lipolysis in isolated human fat cells. J. Biol. Chem. 263: 15553-15560, 1988.

14. Jensen, M. D., M. W. Haymond, J. E. Gerich, P. E. Cryer, and J. M. Miles. Lipolysis during fasting. Decreased suppression by insulin and increased stimulation by epinephrine. J. Clin. Invest. 79: 207-213, 1987.

15. Krief, S., F. Lönnqvist, S. Raimbault, B. Baude, A. van Spronsen, P. Arner, A. D. Strosberg, D. Ricquier, and L. J. Emorine. Tissue distribution of $\beta_{3}$-adrenergic receptor mRNA in man. J. Clin. Invest. 91: 344-349, 1993.

16. Lafontan, M., and M. Berlan. Fat cell adrenergic receptors and the control of white and brown fat cell function. J. Lipid Res. 34: 1057-1091, 1993.

17. Leibel, R. L., E. M. Berry, and J. Hirsch. Metabolic and hemodynamic responses to endogenous and exogenous catecholamines in formerly obese subjects. Am. J. Physiol. 260 (Regulatory Integrative Comp. Physiol. 29): R785-R791, 1991.

18. Liggett, S. B., S. D. Shah, and P. E. Cryer. Human tissue adrenergic receptors are not predictive of responses to epinephrine in vivo. Am. J. Physiol. 256 (Endocrinol. Metab. 19); E600$\mathrm{E} 609,1989$.

19. Maisel, A. S., T. Harris, C. A. Rearden, and M. C. Michel. $\beta$-Adrenergic receptors in lymphocyte subsets after exercise. Alterations in normal individuals and patients with congestive heart failure. Circulation 82: 2003-2010, 1990.

20. Mäki, T., K. Kontula, and M. Härkönen. The beta-adrenergic system in man: physiological and pathophysiological response. 
Regulation of receptor density and functioning. Scand. J. Clin Lab. Invest. 50, Suppl. 201: 25-43, 1990.

21. Motulsky, H. J., S. J. Shattil, and P. A. Insel. Characterization of $\alpha_{2}$-adrenergic receptors on human platelets using $\left[{ }^{3} \mathrm{H}\right]$ yohimbine. Biochem. Biophys. Res. Commun. 97: 1562-1570, 1980

22. Östman, J., P. Arner, H. Kimura, H. Wahrenberg, and P. Engfeldt. Influence of fasting on lipolytic response to adrenergic agonists and on adrenergic receptors in subcutaneous adipocytes. Eur. J. Clin. Invest. 14: 383-391, 1984

23. Scatchard, G. The attractions of proteins for small molecules and ions. Ann. NY Acad. Sci. 51: 660-672, 1949.

24. Schwartz, R. S., L. F. Jaeger, R. C. Veith, and S. Lakshminarayan. The effect of diet or exercise on plasma norepinephrine kinetics in moderately obese young men. Int. J. Obes. 14: 1-11, 1990.

25. Sedmak, J. J., and S. E. Grossberg. A rapid, sensitive, and versatile assay for protein using Coomassie Brilliant Blue G250. Anal. Biochem. 79: 544-552, 1977.
26. Siri, W. E. The gross composition of the body. Adv. Biol. Med. Physiol. 4: 239-280, 1956.

27. Smedes, F., J. C. Kraak, and H. Poppe. Simple and fast solvent extraction system for selective and quantitative isolation of adrenaline, noradrenaline and dopamine from plasma and urine. J. Chromatogr. 231: 25-39, 1981.

28. Sundaresan, P. R., M. Weintraub, L. A. Hershey, B. H. Kroening, J. D. Hasday, and S. P. Banerjee. Platelet alphaadrenergic receptors in obesity: alteration with weight loss. Clin. Pharmacol. Ther. 33: 776-785, 1983.

29. Van Dale, D., W. H. M. Saris, P. F. M. Schoffelen, and F. ten Hoor. Does exercise give an additional effect in weight reduction regimens? Int. J. Obes. 11: 367-375, 1987.

30. Wahrenberg, H., F. Lönnqvist, and P. Arner. Mechanisms underlying regional differences in lipolysis in human adipose tissue. J. Clin. Invest. 84; 458-467, 1989.

31. Weir, J. B. de V. New methods for calculating metabolic rate with special reference to protein metabolism. J. Physiol. Lond. 109: 1-9, 1949 .

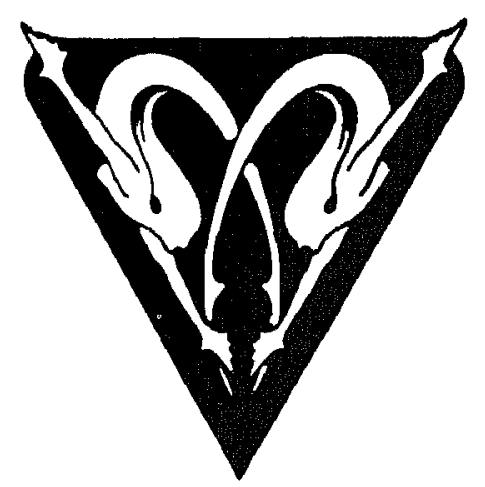

